\title{
ChemComm
}

Cite this: Chem. Commun., 2013, 49, 8522

Received 2nd July 2013 Accepted 1st August 2013

DOI: $10.1039 / c 3 c c 44962 a$

\section{Synthesis, spectroscopic and biological studies of a fluorescent Pt(II) (terpy) based 1,8-naphthalimide conjugate as a DNA targeting agent $\dagger$}

\author{
Swagata Banerjee, ${ }^{a}$ Jonathan A. Kitchen,$\ddagger^{\mathrm{a}}$ Sandra A. Bright, ${ }^{\mathrm{b}}$ John E. O'Brien, ${ }^{\mathrm{a}}$ \\ D. Clive Williams, ${ }^{\text {b }}$ John M. Kelly*a and Thorfinnur Gunnlaugsson*a
}

www.rsc.org/chemcomm

The bi-functional complex [Pt"(terpy)(py-naphth)]( $\left.\mathrm{NO}_{3}\right)_{2}$ (1), incorporating both $2,2^{\prime}: 6^{\prime}, 2^{\prime \prime}$-terpyridine and 4-N,N'-dimethylamino-1,8-naphthalimide moieties, displays a high binding affinity for DNA as well as displaying cytotoxicity towards and inducing apoptosis in malignant cell lines.

The interaction of transition metal ion complexes with biomolecules such as DNA and proteins has comprised a wide area of research in medicinal and supramolecular chemistry. ${ }^{1}$ Platinum(II) based drugs, such as cisplatin (and its structural congeners) are among the leading chemotherapeutics employed in the treatment of cancers such as lung and ovarian cancer as well as lymphomas. ${ }^{2}$ While their application is widespread, cellular resistance has in many cases been found to hamper their efficacy. Consequently, there still remains the need to develop new targeting and more potent Pt(II) ('smart') based drugs. One means to achieve this has been the incorporation of aromatic carrier-structures, such as acridine orange and anthraquinone, into Pt(II) based complexes. ${ }^{3}$

4-Amino-1,8-naphthalimides display good antitumor activities both in vitro and in vivo. ${ }^{4,5}$ These are highly versatile building units with tunable photophysical properties which makes them ideal candidates for use in designing DNA targeting molecules and luminescent probes. ${ }^{4-6}$ We have developed several examples of such 4-amino-1,8-naphthalimide based DNA targeting and cellular imaging agents ${ }^{7,8}$ and have shown that $\mathrm{Ru}(\mathrm{II})$-conjugated naphthalimide structures can give rise to selective photo-induced DNA cleavage. ${ }^{9}$ With the exception of the work of Pérez et al., ${ }^{10}$ to the best of our knowledge, Pt(II) based 1,8-naphthalimide structures have been relatively unexplored as DNA binders and cancer therapeutics. ${ }^{11}$

\footnotetext{
${ }^{a}$ School of Chemistry and Trinity Biomedical Sciences Institute,

Trinity College Dublin, Dublin 2, Ireland.E-mail: jmkelly@tcd.ie, gunnlaut@tcd.ie; Tel: +3531896 1947, +3531896 3459

${ }^{b}$ School of Biochemistry and Immunology and Trinity Biomedical Sciences Institute, Trinity College, Dublin 2, Ireland.E-mail: clive.williams@tcd.ie;

Tel: +35318962596

$\dagger$ Electronic supplementary information (ESI) available: Experimental and Figures ESI 1-20, Tables 1-3. CCDC 939037 (for compound 2) and 939038 (for compound 1). For ESI and crystallographic data in CIF or other electronic format see DOI: $10.1039 / \mathrm{c} 3 \mathrm{cc} 44962 \mathrm{a}$

† Current address: Chemistry, Faculty of Natural \& Environmental Sciences, University of Southampton, Highfield, Southampton, SO17 1BJ.
}

Here we present 1, a novel Pt(II) based 4-amino-1,8-naphthalimide complex, possessing both high DNA binding affinity, good cellular cytotoxicity, as well as desirable luminescent properties for cellular applications.

Compound 1 was formed in $82 \%$ yield in a single step reaction from 4- $N, N$-dimethylamino-1,8-naphthalimide ligand 2 (which was synthesised in two steps using established procedures, see ESI $\dagger$ ), by reacting it with $\left[\mathrm{Pt}(\right.$ terpy) $\mathrm{Cl}] \mathrm{Cl}$ using literature procedures. ${ }^{12,13}$ The complex was fully characterised (see ESI $\dagger$ ). For instance, the HRMS (ESMS) showed the expected isotopic distribution pattern matching that of the calculated one (ESI $\dagger$ ). Compound 3, Scheme 1, has previously been developed in our laboratory as a DNA binder and was employed herein for comparison studies. ${ }^{14}$ Single X-ray quality crystals of both 1 (Fig. 1) and 2 (see ESI $\dagger$ ) were grown from $\mathrm{MeCN}$ and $\mathrm{EtOH}$ solutions, respectively. $\dagger$ Compound $\mathbf{1}$ crystallised in the monoclinic space group $C 2 / c$, with one molecule of $\left[\mathrm{Pt}(\right.$ terpy) $(2)]\left(\mathrm{NO}_{3}\right)_{2}$ and two interstitial $\mathrm{CH}_{3} \mathrm{CN}$ molecules in the asymmetric unit. Here the $\mathrm{Pt}(\mathrm{II})$

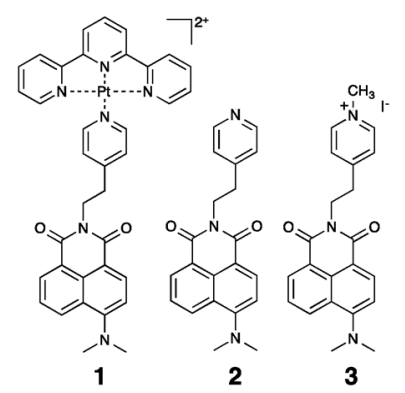

Scheme 1 Structures 1 and $\mathbf{2}$ developed in this study, and $\mathbf{3}$.

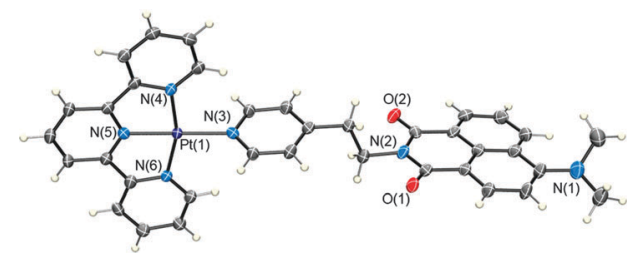

Fig. 1 The X-ray crystal structure of 1 with thermal ellipsoids shown at 30\% probability. Anions and $\mathrm{CH}_{3} \mathrm{CN}$ molecules omitted for clarity. 
adopted a square planar geometry with an $\mathrm{N}_{4}$ coordination environment and cis $\mathrm{N}-\mathrm{Pt}-\mathrm{N}$ angles ranging from $81.1^{\circ}(2)-99.9^{\circ}(2)$, with the Pt $\cdots \mathrm{N}$ bond lengths range from 1.945(7) A to 2.035(6) $\AA$ (see ESI $\dagger$ ). ${ }^{15}$ Strong $\pi \cdots \pi$ stacking interactions were observed between the terpy moieties and the 4-amino-1,8-naphthalimide rings from the neighbouring coplanar complexes with centroid...centroid distances of $3.644 \AA$ and $3.532 \AA$ (see ESI $\dagger$ ). These interactions are repeated throughout the structure to give a twisted head-to-tail arrangement (see ESI $\dagger$ ).

The UV-Vis absorbance, the fluorescence excitation and the emission spectra of $\mathbf{1}$ were recorded at room temperature in water (see ESI $\dagger$ ). The absorption spectrum of 1 showed two sets of bands centred at $340 \mathrm{~nm}$ and $324 \mathrm{~nm}$, respectively. These were assigned to the $\pi-\pi^{*}$ transitions of the terpy ligand. A strong absorption band centred at $450 \mathrm{~nm}$ was also observed, assigned to the internal charge transfer (ICT) transition of the 4-amino-1,8-naphthalimide unit. Excitation of $\mathbf{1}$ at $450 \mathrm{~nm}$ resulted in a broad emission band centred at $550 \mathrm{~nm}(\Phi=0.006)$. The excitation spectrum matched the ICT absorption band indicating that no electronic interaction existed between the two chromophores.

Due to the bifunctional nature of $\mathbf{1}$, we had anticipated that the 4-amino-1,8-naphthalimide unit would be able to modulate the interaction of the $[\mathrm{Pt}(\text { terpy }) \mathrm{X}]^{2+}$ system with DNA, as it is known to function either as a DNA intercalator or a groove binder. To evaluate this and to determine the binding affinity of $\mathbf{1}$ for double stranded DNA, a series of DNA titrations were carried out using salmon testes (st)-DNA. Fig. 2 shows the overall changes in the absorption spectra of 1 (in $10 \mathrm{mM}$ phosphate buffer containing $160 \mathrm{mM} \mathrm{NaNO}$ ). The binding of 1 to DNA results in a $c a .22 \%$ reduction in the absorbance of the ICT band and an $8 \mathrm{~nm}$ red shift in the $\lambda_{\max }$. An even greater hypochromicity is observed for the terpy-localised transitions at $324 \mathrm{~nm}(37 \%)$ and $340 \mathrm{~nm}(49 \%) . \S$ Using these data the intrinsic binding constant $K\left(=4.73 \times 10^{5} \mathrm{M}^{-1}\right)$ and binding site size $n(=2.2)$ were determined using the non-cooperative model of McGhee and von Hippel. ${ }^{16}$ This is a higher binding affinity than reported for other $\mathrm{Pt}(\mathrm{II})$ complexes such as $\left[\mathrm{Pt}(\text { terpy)(4-picoline) }]^{2+}\right.$ (see inset in Fig. 2), [Pt(terpy)HET $]^{+}$and $\left[\mathrm{Pt}(\text { phen)(en) }]^{+}\right.$; all of which lack the additional binding unit incorporated into $1 .{ }^{17}$ Furthermore, this affinity is over an order of magnitude higher than that seen for $3^{14}$ demonstrating the importance of the bi-functional nature of 1 . The strong association of $\mathbf{1}$ with DNA was further verified by carrying out thermal denaturation studies of st-DNA (see ESI $\dagger$ )

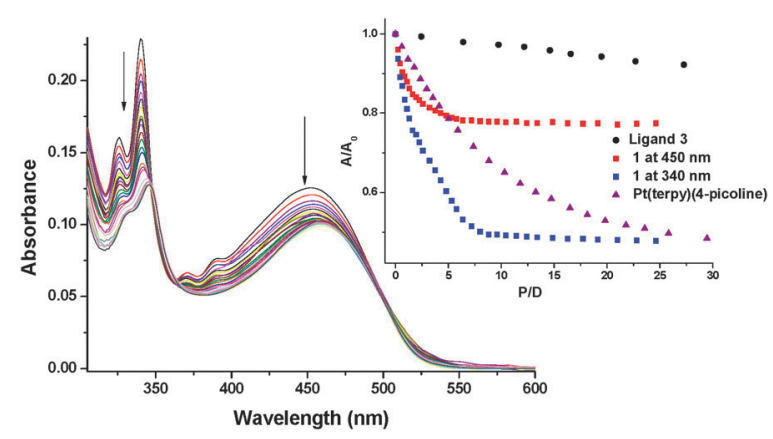

Fig. 2 The UV/vis absorption spectra of $1(16 \mu \mathrm{M})$ in the presence of increasing concentrations of st-DNA $(0-416 \mu \mathrm{M})$ in $10 \mathrm{mM}$ phosphate buffer containing $160 \mathrm{mM} \mathrm{NaNO}_{3}$ (pH 7.0). Inset: a plot of the relative changes in absorbance at various wavelengths vs. P/D for 1 as well as for $\mathbf{3}$ and [Pt(terpy)(4-picoline) $]^{2+}$. which showed that $\mathbf{1}$ strongly stabilises the DNA, as the denaturation process was not complete until above $90{ }^{\circ} \mathrm{C}$. The high binding affinity of 1 for st-DNA was also confirmed in $\mathrm{pH} 7.0$ buffer (see ESI $\dagger$ ) by carrying out ethidium bromide displacement assays (apparent binding constant $2.41 \times 10^{6} \mathrm{M}^{-1}$ ). ${ }^{18}$

Upon addition of st-DNA the fluorescence emission of $\mathbf{1}$ is initially partially quenched (reduction of $22 \%$ and an associated $4 \mathrm{~nm}$ blue shift in the $\lambda_{\max }$, at $P / D=0.6$ ) while further additions of DNA cause an enhancement in the ICT emission intensity (Fig. 3). As with other DNA-binding compounds ${ }^{19}$ the initial emission quenching may be assigned to the aggregation of the metal complex at the outer surface of the DNA, while the subsequent luminescence enhancement is due to the localisation of the chromophore within a more rigid environment and reduced access to quenching by solvent or $\mathrm{O}_{2}$ molecules. As linear dichroism (LD) measurements (see ESI $\dagger$ ) gave negative signals at both $458 \mathrm{~nm}$ and $350 \mathrm{~nm}$ it is apparent both the terpy and the naphthalimide units are (at least partially) intercalated. Circular dichroism (CD) titrations (see ESI $\dagger$ ) also showed the presence of a weak induced negative band in the 300-400 nm region, indicative of terpy group intercalation. However, no induced CD changes were observed for the naphthalimide moiety. These measurements also suggest that groove-binding is not of major importance for these compounds.

As the above studies indicated that 1 possessed a high affinity for DNA, we next investigated the cytotoxicity properties of 1 using an alamar blue cytotoxicity assay. For comparison, the naphthalimide derivatives 2 and $\mathbf{3}$, cisplatin, $[\mathrm{Pt}($ terpy $) \mathrm{Cl}] \mathrm{Cl}$ and $[\mathrm{Pt}($ terpy)(4-picoline) $]^{2+}$ were also measured under identical conditions. Compound 1 showed rapid uptake into cells, and cytotoxicity after incubation for 24 hours $(50 \mu \mathrm{M})$. The cytotoxicity effects are shown in Fig. 4, demonstrating that $\mathbf{1}$ displayed cytotoxicity against the malignant breast cancer cell line MCF-7, with an $\mathrm{IC}_{50}$ value of $16.6 \mu \mathrm{M}$, which is three times lower than that seen for 2 and $3\left(\mathrm{IC}_{50}=50 \mu \mathrm{M}\right.$ and $>100 \mu \mathrm{M})$. While this is comparable to that seen for cisplatin $\left(\mathrm{IC}_{50}=8.8 \mu \mathrm{M}\right), 1$ was found to be significantly more cytotoxic than either $\left[\mathrm{Pt}\right.$ (terpy)Cl] Cl or $[\mathrm{Pt} \text { (terpy)(4-picoline) }]^{2+}\left(\mathrm{IC}_{50}>100 \mu \mathrm{M}\right.$ for both). Further biological studies using fluorescent activated cell sorter (FACS) analysis, showed that $\mathbf{1}$ also induced significant apoptosis in HeLa cells (see ESI $\dagger$ ).

A possible mechanism for the biological action of $\mathbf{1}$ is covalent binding to DNA, as has been shown for $\left[\mathrm{Pt}(\text { terpy)(4-picoline) }]^{2+} .^{20}\right.$ With this in mind, the reaction of $\mathbf{1}$ to the nucleoside guanosine was examined. Using ${ }^{1} \mathrm{H}$ NMR spectroscopy, the changes in both

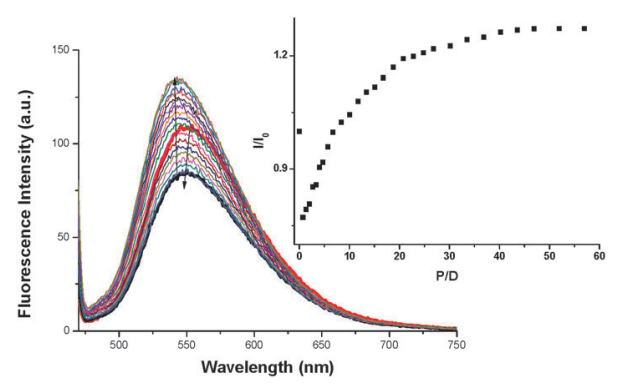

Fig. 3 The steady-state fluorescence spectra of $1(16 \mu \mathrm{M})$ in the presence of increasing concentrations of st-DNA (0-960 $\mu \mathrm{M})$ in $10 \mathrm{mM}$ phosphate buffer containing $160 \mathrm{mM} \mathrm{NaNO}_{3}(\mathrm{pH} 7.0) \lambda_{\mathrm{ex}}=450 \mathrm{~nm}$. Inset: plot of the relative changes in emission intensity at $550 \mathrm{~nm}$ vs. P/D. 


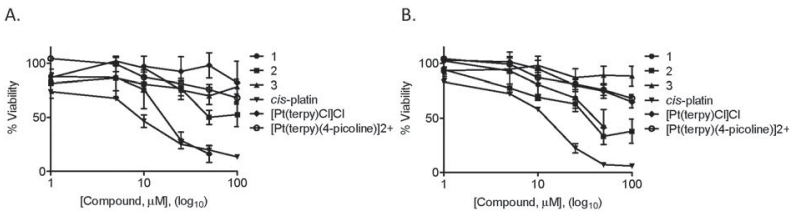

c.
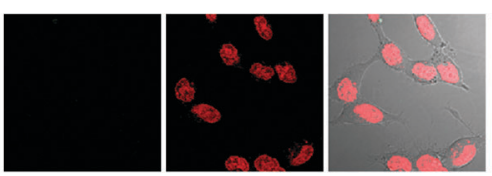

D.

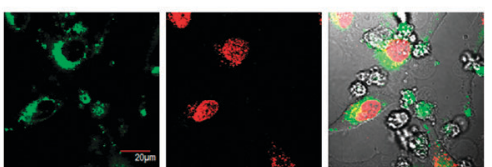

Fig. 4 The antiproliferative effects of 1 on the malignant cell lines (A) MCF-7, (B) HeLa. Confocal images of (C) untreated and (D) 1-treated cells. Green fluorescence $=1$, red fluorescence $=$ DRAQ5 nuclear stain.

the naphthalimide and Pt(terpy) resonances were monitored in the presence of guanosine at room temperature over several days. The results (see ESI $\dagger$ ) showed that significant changes occurred in the ${ }^{1} \mathrm{H}$ NMR spectrum of 1 . After equilibrating for 24 hours, a new resonance appear at $c a$. 6.1 ppm, which was assigned to the $\mathrm{H}^{\prime}{ }^{\prime}$ of $\mathrm{Pt}(\mathrm{II})$ bound guanosine product; being ca. $0.2 \mathrm{ppm}$ downfield shifted compared to the corresponding resonance in the free guanosine form. Concurrently several other new resonances, assigned to the displaced 4-aminonaphthalimide ligand, also appeared. Further changes were observed after 4 days (e.g. two additional doublets appeared at 6.0 and $6.2 \mathrm{ppm}$ and assigned to the $\mathrm{H}^{\prime}{ }^{\prime}$ proton of $\mathrm{Pt}(\mathrm{II})$ bound guanosine). $\uparrow$ While these results suggest coordination of $[\mathrm{Pt}(\text { terpy })]^{2+}$ to nitrogen donor sites of guanosine, further work is needed to determine the structure of these adducts, and this is currently being undertaken.

In summary, we have developed a novel DNA binding Pt-complex 1, and demonstrated that $\mathbf{1}$ has a high affinity for DNA and is readily taken up by breast and cervical cancer cell lines, and induces apoptosis. The DNA binding ability and the cytotoxicity of $\mathbf{1}$ were found to be significantly higher than for Pt(terpy)Cl, [Pt(terpy)(4-picoline) $]^{2+}, 2$ and 3, in MCF-7 cell lines, while being comparable to that seen for cisplatin. We are currently investigating the properties of $\mathbf{1}$ and related Pt(II) derivatives in greater detail; particularly the mode of binding of these to DNA, which can possibly occur in more than one form (see ESI $\dagger$ ).

We would like to thank CSCB, PRTLI Cycle 4 (TG and JMK), TCD (Scholarship to SB and Finical Support to SAB and DCW), IRCSET (JAK Postdoctoral Fellowship) and SFI PI 2010 grant (TG) for financial support.

\section{Notes and references}

$\S$ Clear isosbestic points were also observed at 480 and $345 \mathrm{~nm}$ at low $P / D$ ratios $(P / D 0 \rightarrow 3)$; but slight deviations occurred at higher $P / D$ ratios, suggesting the possibility of more than one mode of binding ( $c f$. Fig. 2 and ESI, $\uparrow$ Fig. S21).

I In contrast, the $\mathrm{H} 8$ proton of guanosine (observed as a singlet at $7.9 \mathrm{ppm}$ ) remained unchanged over this time.
1 (a) M. R. Gill and J. A. Thomas, Chem. Soc. Rev., 2012, 41, 3179; (b) R. B. P. Elmes, K. N. Orange, S. M. Cloonan, D. C. Williams and T. Gunnlaugsson, J. Am. Chem. Soc., 2011, 133, 15862; (c) E. Alessio, Bioinorganic Medicinal Chemistry, ed. E. Alessio, Wiley-VCH Verlag GmbH \& Co., Germany, 2011; (d) P. C. A. Bruijnincx and P. J. Sadler, Curr. Opin. Chem. Biol., 2008, 12, 197; (e) J. G. Vos and J. M. Kelly, Dalton Trans., 2006, 4869; $(f)$ C. X. Zhang and S. J. Lippard, Curr. Opin. Chem. Biol., 2003, 7, 481.

2 Y.-P. Ho, S. C. F. Au-Yeung and K. K. W. To, Med. Res. Rev., 2003, 23, 633.

3 (a) B. E. Bowler and S. J. Lippard, Biochemistry, 1986, 25, 3031; (b) D. Gibson, K. F. Gean, J. Katzhendle, R. Ben-Shoshan, A. Ramu and I. Ringel, J. Med. Chem., 1991, 34, 414; (c) S. Ding, X. Qiao, J. Suryadi, G. S. Marrs, G. L. Kucera and U. Bierbach, Angew. Chem., Int. Ed., 2013, 52, 3350; (d) J. Suryadi and U. Bierbach, Chem.- Eur. J., 2012, 18, 12926; (e) The $\mathrm{Pt}(\mathrm{II})$ complexes of terpy (particularly their photophysical properties) have been used elegantly in many supramolecular applications: K. M. C. Wong and V. W. W. Yam, Acc. Chem. Res., 2011, 44, 424; $(f)$ Pt(II) complexes can also give rise to aggregation in the presence of nucleic acids: C. Yu, K. H. Y. Chan and K. M. C. Wong, Chem. Commun., 2009, 3756; ( $g$ ) Pt(II) complexes have recently been shown to bind to single stranded DNA in a self-assembly manner: C. Yu, K. H. Y. Chan, K. M. C. Wong and V. W. W. Yam, Proc. Natl. Acad. Sci. U. S. A., 2006, 103, 19652. 4 S. Banerjee, E. B. Veale, C. M. Phelan, S. A. Murphy, G. M. Tocci, L. J. Gillespie, D. O. Frimannsson, J. M. Kelly and T. Gunnlaugsson, Chem. Soc. Rev., 2013, 42, 1601.

5 Examples include: (a) M. F. Braña, M. Cacho, M. A. Garcia, B. de PascualTeresa, A. Ramos, N. Acero, F. Llinares, D. Munoz-Mingarro, C. Abradelo, M. F. Rey-Stolle and M. Yuste, J. Med. Chem., 2002, 45, 5813; (b) Q. Yang, P. Yang, X. Qian and L. Tong, Bioorg. Med. Chem. Lett., 2008, 18, 6210; (c) A. Wu, Y. Xu and X. Qian, Bioorg. Med. Chem., 2009, 17, 592; (d) S.-Q. Xie, Y.-H. Zhang, Q. Li, F.-H. Xu, J.-W. Miao, J. Zhao and C.-J. Wang, Apoptosis, 2012, 17, 725; (e) K. J. Kilpin, C. M. Clavel, F. Edafe and P. J. Dyson, Organometallics, 2012, 31, 7031.

6 R. M. Duke, E. B. Veale, F. M. Pfeffer, P. E. Kruger and T. Gunnlaugsson, Chem. Soc. Rev., 2010, 39, 3936.

7 (a) G. J. Ryan, R. B. P. Elmes, S. J. Quinn and T. Gunnlaugsson, Supramol. Chem., 2012, 24, 175; (b) S. Banerjee, J. A. Kitchen, T. Gunnlaugsson and J. M. Kelly, Org. Biomol. Chem., 2012, 10, 3033; (c) E. B. Veale, D. O. Frimannsson, M. Lawler and T. Gunnlaugsson, Org. Lett., 2009, 11, 4040; (d) E. B. Veale and T. Gunnlaugsson, J. Org. Chem., 2010, 75, 5513.

8 R. B. P. Elmes, M. Erby, S. A. Bright, D. C. Williams and T. Gunnlaugsson, Chem. Commun., 2012, 48, 2588.

9 G. J. Ryan, S. J. Quinn and T. Gunnlaugsson, Inorg. Chem., 2007, 47, 401.

10 J. M. Pérez, I. Lopez-Solera, E. I. Montero, M. F. Braña, C. Alonso, S. P. Robinson and C. Navarro-Ranninger, J. Med. Chem., 1999, 42, 5482.

11 Examples include: (a) W. H. Wu, W. T. Wu, S. M. Ji, H. M. Guo, P. Song, K. L. Han, L. N. Chi, J. Y. Shao and J. Z. Zhao, J. Mater. Chem., 2010, 20, 9775; (b) H. M. Guo, S. M. Ji, W. H. Wu, W. T. Wu, J. Y. Shao and J. Z. Zhao, Analyst, 2010, 135, 2832.

12 Y.-C. Lo, T.-P. Ko, W.-C. Su, T.-L. Su and A. H. J. Wang, J. Inorg. Biochem., 2009, 103, 1082.

$13[\mathrm{Pt}(\text { terpy })]^{2+}$ complexes containing 4-pyridineboronic acid ligands were also synthesised for a comparative study: S. S. Hosseini, M. Bhadbhade, R. J. Clarke, P. J. Rutledge and L. M. Rendina, Dalton Trans., 2011, 40, 506.

14 S. Banerjee, J. A. Kitchen, T. Gunnlaugsson and J. M. Kelly, Org. Biomol. Chem., 2013, 11, 5642-5655, DOI: 10.1039/C3OB40370J.

15 I. Eryazici, C. N. Moorefield and G. R. Newkome, Chem. Rev., 2008, 108, 1834.

16 J. D. McGhee and P. H. von Hippel, J. Mol. Biol., 1974, 86, 469.

17 (a) M. Cusumano, M. L. Di Pietro and A. Giannetto, Inorg. Chem., 1999, 38, 1754; (b) M. Howe-Grant and S. J. Lippard, Biochemistry, 1979, 18, 5762.

18 D. L. Boger, B. E. Fink, S. R. Brunette, W. C. Tse and M. P. Hedrick, J. Am. Chem. Soc., 2001, 123, 5878.

19 (a) S. Mansouri, S. Fery-Forgues, B. Meunier and N. Paillous, J. Chem. Soc., Perkin Trans. 2, 1996, 1649; (b) M. L. Clark, R. L. Green, O. E. Johnson, P. E. Fanwick and D. R. McMillin, Inorg. Chem., 2008, 47, 9410; (c) S. Biagini, A. Bianchi, T. Biver, A. Boggioni, I. V. Nikolayenko, F. Secco and M. Venturini, J. Inorg. Biochem., 2011, 105, 558; (d) C. Bazzicalupi, A. Bencini, A. Bianchi, T. Biver, A. Boggioni, S. Bonacchi, A. Danesi, C. Giorgi, P. Gratteri, A. M. Ingraín, F. Secco, C. Sissi, B. Valtancoli and M. Venturini, Chem.-Eur. J., 2008, 14, 184.

20 (a) A. McCoubrey, H. C. Latham, P. R. Cook, A. Rodger and G. Lowe, FEBS Lett., 1996, 380, 73; (b) G. Lowe and T. Vilaivan, J. Chem. Soc., Perkin Trans. 1, 1996, 1499. 